J. Dairy Sci. 98:8545-8553

http://dx.doi.org/10.3168/jds.2015-9983

(C) American Dairy Science Association ${ }^{\circledR}, 2015$.

\title{
Dried distillers grains with solubles do not always cause late blowing in baby Swiss cheese
}

\author{
V. Manimanna Sankarlal, ${ }^{*}$ E. D. Testroet, $†$ D. C. Beitz, $\nmid$ and S. Clark ${ }^{* 1}$ \\ *Department of Food Science and Human Nutrition, and \\ †Department of Animal Science, lowa State University, Ames 50011
}

\begin{abstract}
Late blowing in Swiss cheese, a result of unwanted gas production, is unacceptable to consumers and causes economic loss to manufacturers. Cheese processors have raised concerns that feeding dried distillers grains with solubles (DDGS) to cows leads to this defect, in part because of clostridial spores. We hypothesized that spores in DDGS would affect the quality of milk and baby Swiss cheese by promoting late-blowing defects. Thirty healthy multiparous and mid-lactation Holstein cows were fed total mixed ration containing DDGS $(0,10$, and $20 \% ; 10$ cows per treatment group) by dietary dry matter in a $3 \times 3$ Latin square design. One complete milking from all cows within a treatment was collected and pooled for baby Swiss cheese, twice within each month of the 3-mo study. Additionally, individual milk samples from the 3 milkings of one day were collected weekly for proximate analysis. Incubation in reinforced clostridial medium-lactate medium tubes inoculated with milk, cheese, total mixed ration, or manure showed gas formation. Conversely, the DDGS used in our study did not contain gas-producing, spore-forming bacteria. Feeding 20\% DDGS decreased milk fat percent and increased the solids nonfat, protein, and lactose percent of milk. After $60 \mathrm{~d}$ of ripening, baby Swiss cheese had typical propionic acid Swiss cheese aroma. Regardless of dietary treatment, pinholes, slits, splits, cracks, or a combination of these, were seen throughout most cheeses. Feeding of DDGS increased the amount of long-chain unsaturated fatty acids and decreased shortchain and most medium-chain fatty acids in the baby Swiss cheese. Although feeding cows diets with DDGS modified milk composition, and subsequently cheese composition, DDGS was not a source for gas-producing, spore-forming bacteria or for quality defects in Swiss cheese. Rather, the gas-producing, spore-forming
\end{abstract}

Received June 18, 2015.

Accepted August 14, 2015.

${ }^{1}$ Corresponding author: milkmade@iastate.edu bacteria likely originated from the environment or the cows themselves.

Key words: eyes, Clostridium, spores, total mixed ration, quality

\section{INTRODUCTION}

The late-blowing defect in Swiss-style cheese varieties can be described as the appearance of undesirable slits, splits, cracks or blown areas in the cheese. Late-blown cheese is unacceptable to consumers and high-speed slicing operations. Such cheeses cannot be sold at full value and thus lead to economic losses to cheese producers (White et al., 2003). Reports on late blowing in cheeses have raised concerns that feeding distillers grains to dairy herds contributed to the late blowing in cheese (Houck et al., 2007).

Eye formation in Swiss cheese is considered desirable when it is formed by carbon dioxide produced as a result of fermentation by starter cultures (Propionibacterium freudenreichii ssp. shermanii). However, contamination by nonstarter bacteria such as Clostridium tyrobutyricum or Clostridium butyricum could lead to the production of hydrogen gas $\left(\mathrm{H}_{2}\right)$ and hydrogen sulfide gas $\left(\mathrm{H}_{2} \mathrm{~S}\right)$, in addition to carbon dioxide $\left(\mathrm{CO}_{2}\right)$, butyric acid, butanoic acid, and acetic acid, by utilization of lactate substrate (Fox et al., 2000; Fröhlich-Wyder and Bachmann, 2007). The $\mathrm{H}_{2}$ gas is less soluble in the cheese body when compared with $\mathrm{CO}_{2}$, thus leading to production of unforeseen large openings in the cheese body. Excessive gas $\left(\mathrm{CO}_{2}\right.$ and $\left.\mathrm{H}_{2}\right)$ elevates the gas pressure higher than the structure of curd can withstand, leading to blowing or exploding in the cheese body (Hutkins, 2006). Excessive gas also leads to variation of eye size (forming too large, too small, or too numerous eyes), and the resultant cheese body has eyes that are usually split, cracked, or both, leading to split defects or late-blowing defects. Unforeseen gas formation in the cheese, such as $\mathrm{CO}_{2}, \mathrm{H}_{2}$, or $\mathrm{H}_{2} \mathrm{~S}$, is usually associated with unclean and strong atypical off-flavors (FröhlichWyder and Bachmann, 2007; Cakir and Clark, 2009). Another theory by Hettinga et al. (1974) linked propi- 
onibacteria strains that are active at low temperatures to the eyes formed by late fermentation after the cheese is moved from the warm room to the cold room. The temperature difference when the cheese is moved from the warm room to the cold room increases the rigidity, resulting in a brittle cheese body. Any further gas production by nonstarter propionibacteria in the cold room could also contribute to slit formation because the cheese body is incapable of accommodating gas bubbles (White et al., 2003; Daly et al., 2010).

Various researchers have proposed several hypotheses to explain the mechanism of split formation. These hypotheses include (1) the elasticity of cheese and contribution of proteolysis (Johnson, 2001); (2) secondary fermentation where starter or nonstarter bacteria produce gas during or after (or both) the normal warm room ripening, causing splitting and irregular eyes (Park et al., 1967; Hettinga et al., 1974; Hutkins, 2006; Fröhlich-Wyder and Bachmann, 2007); and (3) presence of C. tyrobutyricum spores (Dasagupta and Hull, 1989; Steffen et al., 1993; Fröhlich-Wyder and Bachmann, 2007), with low-quality feed with high clostridial spore count acting as source of contamination in milk and in the cow environment (Dasagupta and Hull, 1989; Houck et al., 2007).

With ethanol production being a major industry in the Midwest, utilization of dried distillers grains with solubles (DDGS) as a protein source in animal feeding is common and generally considered economical. Consequently, understanding the effects of DDGS inclusion in the diet of dairy cows on quality markers of milk that contribute to cheese production is of high priority to cheese processors in the Midwest. The hypothesis of this research was that increasing inclusion of DDGS in the diet of lactating Holstein dairy cows would lead to greater incidence of defects when compared with control-fed cows. To test this hypothesis, the objective of this research was to investigate the effect of feeding diets with 3 concentrations of DDGS $(0,10$, and $20 \%$ of dietary DM) to dairy cows on milk and cheese composition, eye formation, and gas-producing, spore-forming bacteria present in milk and cheese.

\section{MATERIALS AND METHODS}

\section{Experimental Design}

Thirty healthy multiparous and mid-lactation Holstein cows from the Iowa State University Dairy Farm (Ames) were selected and stratified by DIM and parity to 1 of the 3 dietary treatment groups with 10 cows in each treatment group in a $3 \times 3$ Latin square with repeated measures. The diets were formulated to be isonitrogenous $(16.5 \% \mathrm{CP})$ and isoenergetic. The treatments diets were (1) TMR with no DDGS, (2) TMR with 10\% DDGS (Heartland Cooperative, Prairie City, IA) as dietary DM, and (3) TMR with 20\% DDGS as dietary DM. Cows were trained to use Calan gates (American Calan Inc., Northwood, NH), and each cow had ad libitum access to food and water. After each treatment period, the cows were switched to the next diet, such that each cow served as her own control for a total of 3 treatments. Individual milk samples from all of the 3 milkings from each cow were collected and pooled to represent an entire milking from that individual cow every week during each 28 -d treatment period (Tuesdays) and proximate analysis was performed (Wednesdays). The first $13 \mathrm{~d}$ of each $28-\mathrm{d}$ period were considered to be an acclimation period and were thus not included in the milk proximate analyses (i.e., proximate analyses were performed during wk 2,3 , and 4 of each treatment period).

\section{Proximate Analysis}

The milk from each cow was collected throughout one entire milking by a Boumatic milking system (Boumatic, Madison, WI), then poured into sanitized blue 60-mL snap-cap bottles (Fisher Scientific, Pittsburgh, PA), transported to the laboratory within $30 \mathrm{~min}$ of collection, and refrigerated $\left(\sim 4^{\circ} \mathrm{C}\right)$. Proximate analyses (percent lactose, fat, and protein) were performed the following day on the individual milk samples, in duplicate, by using a Lacticheck-01 RapiRead Milk Analyzer (Page \& Pedersen Intl. Ltd., Hopkinton, MA). The chilled milk samples were inverted gently inside the blue snap-cap bottles to homogenize any separated cream on the cap of the bottle and tempered to room temperature $\left(22 \pm 2^{\circ} \mathrm{C}\right)$ before analysis. Introduction of air bubbles was avoided while mixing the sample to minimize error in the readings from the Lacticheck ultrasonic milk analyzer.

\section{Milk Collection for Cheese Making}

Milk from one complete milking of each treatment group $(0,10$, and $20 \%$ DDGS) was collected twice during wk 3 and 4 of each of the three 28-d periods. For cheese-making, the morning milking (approximately $0630 \mathrm{~h}$ ) was collected during the farm's usual milk collection routine. Typically, milk from 2 groups of 10 cows each on Friday and 1 group of 10 cows on Saturday were collected (milk of 10 cows pooled). The milk cans and dump buckets were washed with automatically diluted Oasis Enforce (Ecolab, St. Paul, MN) and sanitized with automatically diluted Mikroklene 
(Ecolab) iodine-based sanitizer. At the dairy farm, the teats were sanitized with $1,000 \mathrm{mg} / \mathrm{kg}$ chlorine predip (ECAcept Technology, Zurex PharmAgra LLC, Middleton, WI) and wiped dry with individual towels before collecting milk from each cow by the Boumatic milking system. Milk was collected in sanitized dump buckets and transferred into sanitized, labeled aluminum milk cans. The milk cans were then transported, at ambient temperature, to the Center for Crops Utilization Research pilot plant in the Food Sciences Building at Iowa State University (Ames) within 20 min of collection of milk from the last cow. The milk cans were immediately placed in the walk-in cooler $\left(4^{\circ} \mathrm{C} \pm 2^{\circ} \mathrm{C}\right)$ until further processing (within $60 \mathrm{~min}$ ). Those who collected milk at the dairy farm changed into clean clothes before participation in cheese making to minimize additional external contamination of milk to be used for cheese production.

Prior to proximate analysis, the milk was agitated, filtered through cheesecloth, and weighed before sampling for fat and protein quantification. Measured percentage fat and protein were used to standardize milk to the target fat:protein ratio $(0.88 \pm 0.05)$. If the fat:protein ratio was not $0.88 \pm 0.05$, the milk was separated and standardized, and cream or skim from the milk collected from the same experimental cows were added to raise or lower the ratio, respectively. Milk was separated using a Type LWA 205 Westfalia Separator (219 rpm in 2.5 dial setting, Dusseldorf, Germany).

Milk was subsequently HTST pasteurized with a UHT/HTST Electric model 25HV Hybrid pasteurizer (MicroThermics, Raleigh, NC). The pasteurization temperature and time was set at $73.5^{\circ} \mathrm{C}$ for $15 \mathrm{~s}$ (flow rate $4 \mathrm{~L} / \mathrm{min})$. Upon exit from the pasteurizer $\left(\sim 37^{\circ} \mathrm{C}\right)$, milk entered 1 of 2 cheese vats and was cooled to $33^{\circ} \mathrm{C}$ by running cold water in the jacketed vat, and with gentle agitation of the milk.

Baby Swiss cheese was made by using cultures of Streptococcus thermophilus SSC $17(0.8 \mathrm{~g} / 45.4 \mathrm{~kg}$ of milk, Chr. Hansen, Milwaukee, WI), Lactobacillus helveticus Helv A (0.08 g/45.4 kg, DuPont Danisco, Madison, WI), and Propionibacterium freudenreichii ssp. shermanii $(0.5 \mathrm{~g} / 45.4 \mathrm{~kg}$, Chr Hansen PS-1). Coagulant (Maxiren, DSM, Delft, the Netherlands) was diluted with cold water to a ratio of 1:40 and added at $4 \mathrm{~mL} / 45$ $\mathrm{kg}$ of milk, and the cheese curd was allowed to set for 25 to $30 \mathrm{~min}$. The curd was tested for firmness visually and manually cut with $12-\mathrm{cm}$ wire curd knives. About $25 \%$ of vat volume of whey was initially removed, followed by constant stirring and addition of water (3 to $5 \%$ of the vat volume) at $33^{\circ} \mathrm{C}$; the forework proceeded for $35 \mathrm{~min}$ at $33^{\circ} \mathrm{C}$. Gradually, the curds were cooked by increasing the temperature to $40^{\circ} \mathrm{C}$ over a 15 -min period, and then to $46^{\circ} \mathrm{C}$ over a 10 -min period by adding steam to the jackets of the vat. Warm water $(\sim 10 \%$ of the vat volume) was added at $44^{\circ} \mathrm{C}$ to facilitate the rise in temperature of the cheese to $47.8^{\circ} \mathrm{C}$, where the curds were held for $42 \mathrm{~min}$ (postwork). After postwork, and at a target $\mathrm{pH}$ of 6.4 , whey was removed. Cheese curds were collected into perforated cheese molds made by drilling holes in 5-gallon plastic storage basin containers. Blocks were pressed under whey by using the same style plastic basin filled with water $(16 \mathrm{~kg}$ hydraulic weight) for $15 \mathrm{~min}$. The whey was drained completely and the cheese block was pressed for about $5 \mathrm{~h}$. The $\mathrm{pH}$ of the curd was measured (Accumet Basic AB15, Fisher Scientific Inc.) after $2 \mathrm{~h}$, and the curd block was flipped. The press was removed, and cheese was fermented in an empty basin for an additional 8 to $10 \mathrm{~h}$ at $28^{\circ} \mathrm{C} \pm 3^{\circ} \mathrm{C}$. The pressing time was based on the time required for the $\mathrm{pH}$ of the cheese to drop from 6.4 to 5.25. Brining was carried out in saturated brine containing $23 \% \mathrm{NaCl}$ and $0.38 \% \mathrm{CaCl}_{2}$, for 12 h. Cheese blocks were vacuum-packed in clear vacuum seal bags (Fisher Scientific Inc.) with a Koch vacuum packing machine (Koch Equipment LLC, Kansas City, MO). Cheeses were stored at $10^{\circ} \mathrm{C}$ for $7 \mathrm{~d}$ (precool), 22 $\pm 3^{\circ} \mathrm{C}$ for $21 \mathrm{~d}$ (warm room), and $4^{\circ} \mathrm{C}$ for $60 \mathrm{~d}$ (cold room). Cheeses were analyzed for composition, quality, and gas-producing, spore-formers after $60 \mathrm{~d}$ in the cold room. The cheeses were cut into pieces for analysis, and pictures were taken (Figure 1).

Staff at the Agricultural Utilization Research Institute (Marshall, MN) carried out the cheese proximate analysis. Standard methods were followed for measuring different components of cheese [moisture: method 926.08; protein: 2001.14; ash: method 935.42; fat: method 933.05; calcium: method 991.25; sodium: method 991.25 (all AOAC International, 2000), and Tarladgis et al., 1960]. Agricultural Utilization Research Institute staff also carried out the cheese FA profile analysis (AOCS Ce 2-66, Ce 1j-07).

\section{Spore Testing on DDGS, TMR, Milk, Cheese, and Manure}

Twenty-five grams of sample (DDGS, TMR (with and without DDGS), milk, baby Swiss cheese, and manure) were mixed in $225 \mathrm{~mL}$ of $0.1 \%$ peptone water by using a stomacher 400C (Seward, Davie, FL) for $30 \mathrm{~s}$. From the stomached sample, about 10 to 20 $\mathrm{mL}$ of liquid sample was transferred to a $30-\mathrm{mL}$ glass test tube, heated to $80^{\circ} \mathrm{C}$ for $10 \mathrm{~min}$ in a water bath, and cooled immediately after $10 \mathrm{~min}$ to kill most of the vegetative cells and to encourage germination of spores. One milliliter of the heat-shocked sample was 
A.

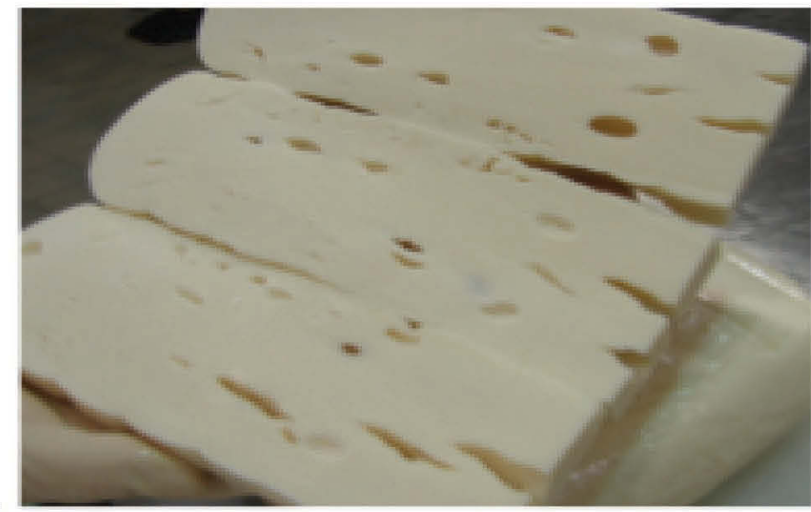

C.

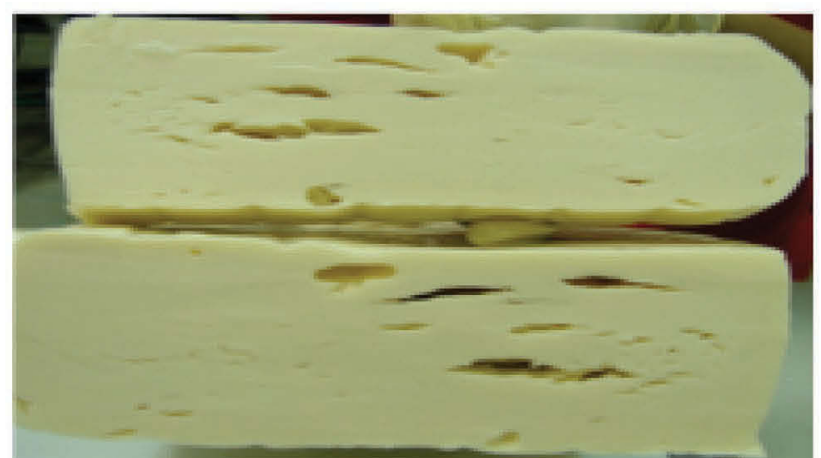

B

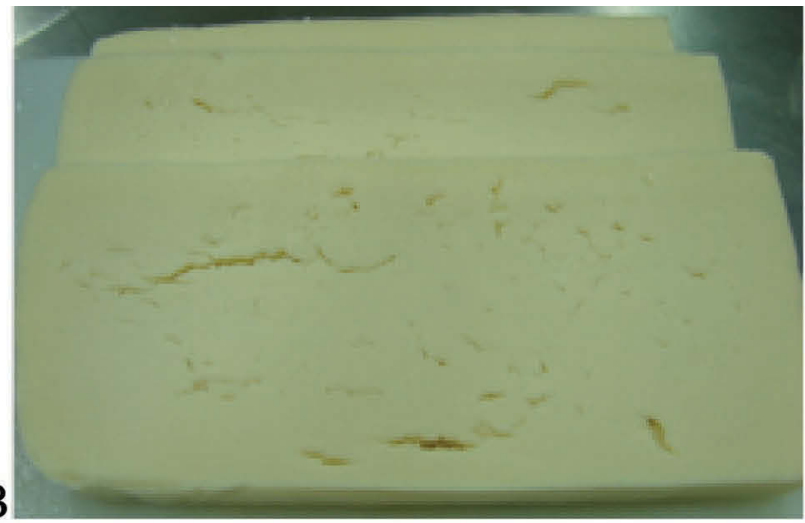

$\mathrm{D}$

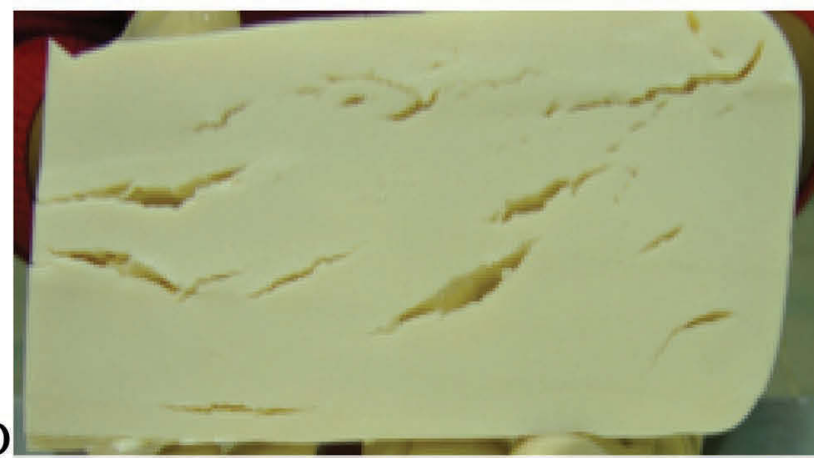

Figure 1. Representative images of defects in experimental baby Swiss cheese made from the milk of cows fed TMR and partial substitution of TMR with 10 to $20 \%$ dried distillers grains with solubles (DDGS). (A) Cheese exhibits a few eyes and slits; (B) cheese exhibits pin-holes and cracks; (C) cheese exhibits checks; (D) cheese exhibits splits throughout the cheese body. Color version available online.

transferred to a clean autoclaved test tube with $9 \mathrm{~mL}$ of modified reinforced clostridial medium (RCM) with lactate (Dasagupta and Hull, 1989) broth and a Durham tube (Fisher Scientific), then incubated at $35^{\circ} \mathrm{C}$ in anaerobic conditions by using GasPak (BD Chemicals, Sparks, MD). The modified RCM-lactate broth was made by mixing beef extract (10 g), yeast extract ( $3 \mathrm{~g}$; BD Chemicals), sodium chloride (5 g), L-cysteine (0.5 $\mathrm{g})$, soluble starch (1 g; Fisher Scientific), tryptone (10 $\mathrm{g})$, sodium lactate syrup $(10 \mathrm{~mL})$, sodium acetate $\cdot 3 \mathrm{H}_{2} \mathrm{O}$ (8 g; Sigma Aldrich, St. Louis, MO), and agar (2 g; $\mathrm{BD}$ Chemicals) in $1 \mathrm{~L}$ of distilled water and was subsequently autoclaved. The experiment was conducted in duplicate. Gas formation in the samples was observed by checking Durham tubes for the presence of gas after 24 to $48 \mathrm{~h}$.

\section{Statistical Analysis}

During the feeding trials, the cows diagnosed with mastitis or any other sickness were removed from the study. The study started with 30 cows in period 1 but decreased to 25 by the end of the study. All statisti- cal analysis was carried out by using SAS 9.3 (SAS Institute Inc., Cary, NC). A mixed model was used with diet, period, parity, and diet by trial interaction as fixed effects, and DIM as covariate. Analysis was done as repeated measures with date as the repeated statement and cow nested within diet and trial as the subject for proximate analysis of milk and the repeated statement of date with the subject being an individual cheese quality measure (e.g., pH, moisture). To minimize the carryover effects, the first 2 wk of each period was considered as an acclimation period and was not included in the statistical analysis. Tukey-Kramer multiple pairwise comparison adjustment was used to identify significant differences at $(P<0.05)$.

\section{RESULTS AND DISCUSSION}

\section{Milk Proximate Analysis}

After excluding the first $13 \mathrm{~d}$ of data from each period, milk samples were collected from each cow for a total of 10 times throughout the entire experiment. Milk protein \% and SNF \% increased significantly $(P$ 
Table 1. Summary of proximate analysis conducted on milk collected every week from individual cows during the dried distillers grains with solubles (DDGS) feeding study

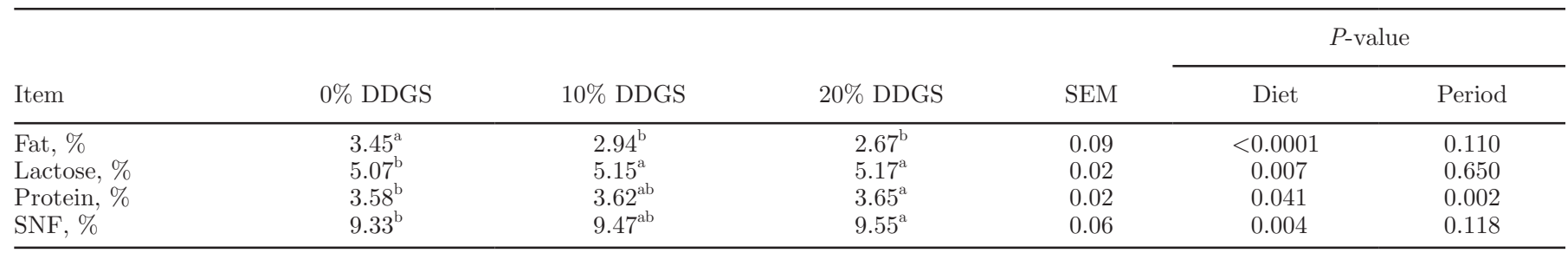

${ }^{\mathrm{a}, \mathrm{b}}$ Values with different superscripts are significantly different $(P<0.05)$.

$<0.05$; Table 1) with $20 \%$ dietary inclusion of DDGS. These findings were supported by our previous research (Testroet et al., 2015) where the treatments included 10 and $25 \%$ DDGS in TMR. The same trend of increase in protein percentage was not observed by previous studies (Anderson et al., 2006; Kleinschmit et al., 2006) when cows were fed with $20 \%$ DDGS. The milk yield in those studies, however, was increased by the $20 \%$ DDGS treatment, which could have diluted the protein and decreased the protein concentration. In our study, the protein yield remained unaffected by the DDGS treatments with a nonsignificant decrease in milk yield. The dietary change could have concentrated the protein in the milk, which led to significantly higher protein in milk from 20\% DDGS treatment.

The milk from cows fed 10 and 20\% DDGS had significantly lower fat percentage $(P<0.05$; Table 1$)$ compared with the milk from cows fed $0 \%$ DDGS. The same pattern of depression in milk fat percentage and daily milk fat yield was not observed in previous studies that fed DDGS to dairy cows (Anderson et al., 2006; Kleinschmit et al., 2006). However, milk fat content could be highly influenced by dietary fat content. Dairy nutritional experts limit the dietary inclusion of DDGS to $20 \%$ (Anderson et al., 2006) because increased unsaturated fatty acids (i.e., the corn oil in DDGS) in the diet of a ruminant could lead to milk fat depression. Indeed, Testroet et al. (2015) showed that feeding unsaturated dietary fats from 10 and 25\% DDGS treatment caused significant $(P<0.05)$ milk fat depression, which supported the results of our current study.

Lactose percentage of the milk increased significantly with 10 and $20 \%$ DDGS inclusion $(P<0.01$; Table 1$)$, which supports the findings of Tanaka et al. (2011), who observed higher $(P<0.05)$ lactose content in milk when cows were fed $20 \%$ DDGS compared with a control group. The US Grains Council (2012) additionally reported a nonsignificant $(P>0.05)$ increase in lactose content when cows were fed $10 \%$ DDGS. The increase in lactose may be relevant with respect to eye formation, although the present study did not directly evaluate the effect of lactose on eye formation. Lactose is the primary substrate for starter cultures used in the cheese production process. Lactose is split into glucose and galactose by the starter cultures (S. thermophilus, L. helveticus) and fermented to D- or L-lactic acid, or both. Propionibacteria grow and preferentially metabolize L-lactate to propionate, acetate, and $\mathrm{CO}_{2}$ once the cheeses are transferred into the warm room (McSweeney and Sousa, 2000). Alterations in the concentration of lactose available for metabolism by starter and nonstarter may modify the maturation and subsequent properties of cheese. Excess lactose, glucose, galactose, lactate, or a combination of these may provide a substrate for secondary fermentation and late blowing.

Eye formation in Swiss cheese depends upon its appropriate physiochemical and mechanical properties. If the milk itself contained higher lactose, then it is likely that the lactose content at the start of fermentation was also high. Hutkins (2006) mentioned that it is very important that the cheese curds contain the right amount of lactose after the cooking process for the final $\mathrm{pH}$ to be 5.2 . A pH of less than 5.2 would increase the chances of fracturing because of excessive gas production or incidence of blind cheese (Lawrence et al., 1984). Finally, proper eye formation depends on the presence of seeding points for eye nucleation, proper acidification, and calcium solubilization, molding and pressing, elastic cheese body, and low storage temperature to reduce plasticity of the cheese body (Guggisberg et al., 2015).

\section{Milk and Cheese Analysis}

Because protein in cheese milk slightly increased with inclusion of DDGS (Table 1), fat:protein ratio of raw milk decreased with inclusion of DDGS (data not shown). However, standardized fat:protein ratios were within 0.03 of target (0.88) among all treatments (data not shown). Baby Swiss cheese standards of identity requirements for a minimum $45 \%$ fat in solids and maximum $43 \%$ moisture (ATCP, 1996) were satisfied (Table $2)$. The lack of significant differences $(P>0.05)$ in cheese $\mathrm{pH}$, moisture, fat, sodium, and salt in moisture 
based on diet (Table 2) is expected because the goal was to perform procedures consistently among batches of cheese.

No trained sensory evaluation panel was conducted on the cheese, but author S. Clark has extensive experience with sensory evaluation of dairy products, including Swiss-type cheeses. After aging (including 7 $\mathrm{d}$ of cool storage, $21 \mathrm{~d}$ of warm room, and $60 \mathrm{~d}$ of cold room), baby Swiss cheeses had a typical propionic acid Swiss cheese aroma. However, more lactic acid aroma than expected in typical baby Swiss was present in cheeses from 10 and $20 \%$ diets when compared with the aroma in the control cheese, possibly explained by the significantly higher lactose in milk from the 10 and $20 \%$ DDGS-fed cows than the control milk (Table 1). Additionally, some cooked eggy $\mathrm{H}_{2} \mathrm{~S}$ aroma was apparent in the 10 and 20\% DDGS cheeses. Because spoilage organisms such as C. tyrobutyricum and C. butyricum are capable of metabolizing lactose into $\mathrm{H}_{2} \mathrm{~S}, \mathrm{H}_{2}$, butyrate, and $\mathrm{CO}_{2}$ (Fox et al., 2000; Cakir and Clark, 2009), it was thought that the aroma was a sign of clostridial contamination.

Eye distribution and cheese body and texture were atypical in both control and treatment cheeses. Although proximate analysis revealed that all cheeses met the standard of identity for Swiss cheese (Table 2 ), all cheeses were less rubbery/elastic and felt more moist than typical baby Swiss. Slits (Figure 1A), pinholes (Figure 1B), cracks (Figure 1B), checks (Figure $1 \mathrm{C}$ ), and splits (Figure 1D) were evident in all cheeses. Glossy, round eyes were rarely found (Figure 1A) beyond period 1, regardless of dietary treatment. Blindness was also occasionally exhibited, most typically within 1/4-inch $(0.64 \mathrm{~cm})$ of the cheese surface. Several cheeses exhibited long longitudinal splits, cracks, or blown areas, which tended to appear along curd junctions, preventing a tight, closed body (Figure 1), but mechanical openings were not present. The defects may have resulted from overly high rate of $\mathrm{CO}_{2}$ production in the warm room, coupled with a high rate of gas diffusion out of the cheese body (Guggisberg et al., 2015).

In the present work, approximately $15 \%$ water was added to the curd/whey mixture during cooking in an effort to reduce the risk of late fermentation. It was reported by Jaros et al. (1997) that water addition yields cheese with higher moisture content and higher $\mathrm{pH}$, which is favorable for P. shermanii growth, and should yield cheese with an elastic body (Jaros et al., 1997). Yet malformations were observed in all cheeses in the present study. Though within standards (ATCP, 1996), the moisture contents in the cheeses (Table 2) were higher than those of White et al. (2003), who reported reduced splitting in cheeses with lower moisture content. Other authors have reported that elevated water content accelerates enzymatic proteolysis and makes cheese body more brittle in the later ripening stage, promoting the formation of cracks (Fröhlich-Wyder and Bachmann, 2007; Daly et al., 2010).

On average, final cheese $\mathrm{pH}$ tended to be lower than the recommended target of 5.2 (Table 2), perhaps because of overactive cultures resulting from high moisture and low (but not atypical) salt (mean 1.2-1.3\%). Consequently, mean calcium concentrations (7.4-7.8 $\mathrm{mg} / \mathrm{g})$ were lower than typical Swiss cheese $(7.9 \mathrm{mg} / \mathrm{g})$. Because calcium is a structural component of cheese matrix, the lower calcium may also partially explain the cheese softness and resulting body defects. Solubilization of calcium due to acidification has recently been reported as one of the factors that influences eye defects in Swiss cheese (Guggisberg et al., 2015). Previously, White et al. (2003) did not find any correlation between the factors such as $\mathrm{pH}$, fat, protein, and calcium contents in split and nonsplit cheese.

Cheese FA profile revealed that long-chain unsaturated FA increased with DDGS feeding (Table 3). All short- (C4, C6, C8, C10) and medium-chain (C14, C16, C18) SFA decreased significantly $(P<0.05)$. No changes were seen in $\mathrm{C} 15, \mathrm{C} 17, \mathrm{C} 19$, and $\mathrm{C} 20$, which

Table 2. Summary of chemical analysis conducted on all baby Swiss cheeses made from milk of cows fed TMR and partial substitution of TMR with 10 to $20 \%$ dried distillers grains with solubles (DDGS)

\begin{tabular}{|c|c|c|c|c|c|c|}
\hline Item & $0 \%$ DDGS & $10 \%$ DDGS & $20 \%$ DDGS & SEM & \multicolumn{2}{|c|}{$P$-value } \\
\hline $\mathrm{pH}$ & 5.15 & 5.14 & 5.13 & 0.02 & 0.795 & 0.146 \\
\hline Fat, $\%$ & 30.18 & 29.70 & 29.50 & 1.39 & 0.945 & 0.780 \\
\hline Fat in solids, \% & 51.37 & 50.92 & 50.33 & 2.19 & 0.945 & 0.735 \\
\hline Protein, \% & 23.83 & 23.60 & 24.13 & 0.89 & 0.920 & 0.679 \\
\hline Sodium, mg/g & 4.79 & 4.74 & 4.98 & 0.11 & 0.508 & 0.375 \\
\hline Salt, $\%$ & 1.22 & 1.21 & 1.27 & 0.02 & 0.497 & 0.356 \\
\hline Salt in moisture, \% & 2.94 & 2.90 & 3.07 & 0.03 & 0.208 & 0.173 \\
\hline
\end{tabular}


Table 3. Fatty acid composition of baby Swiss cheese from milk of cows fed TMR and partial substitution of TMR with 10 to $20 \%$ dried distillers grains with solubles (DDGS ${ }^{1}$

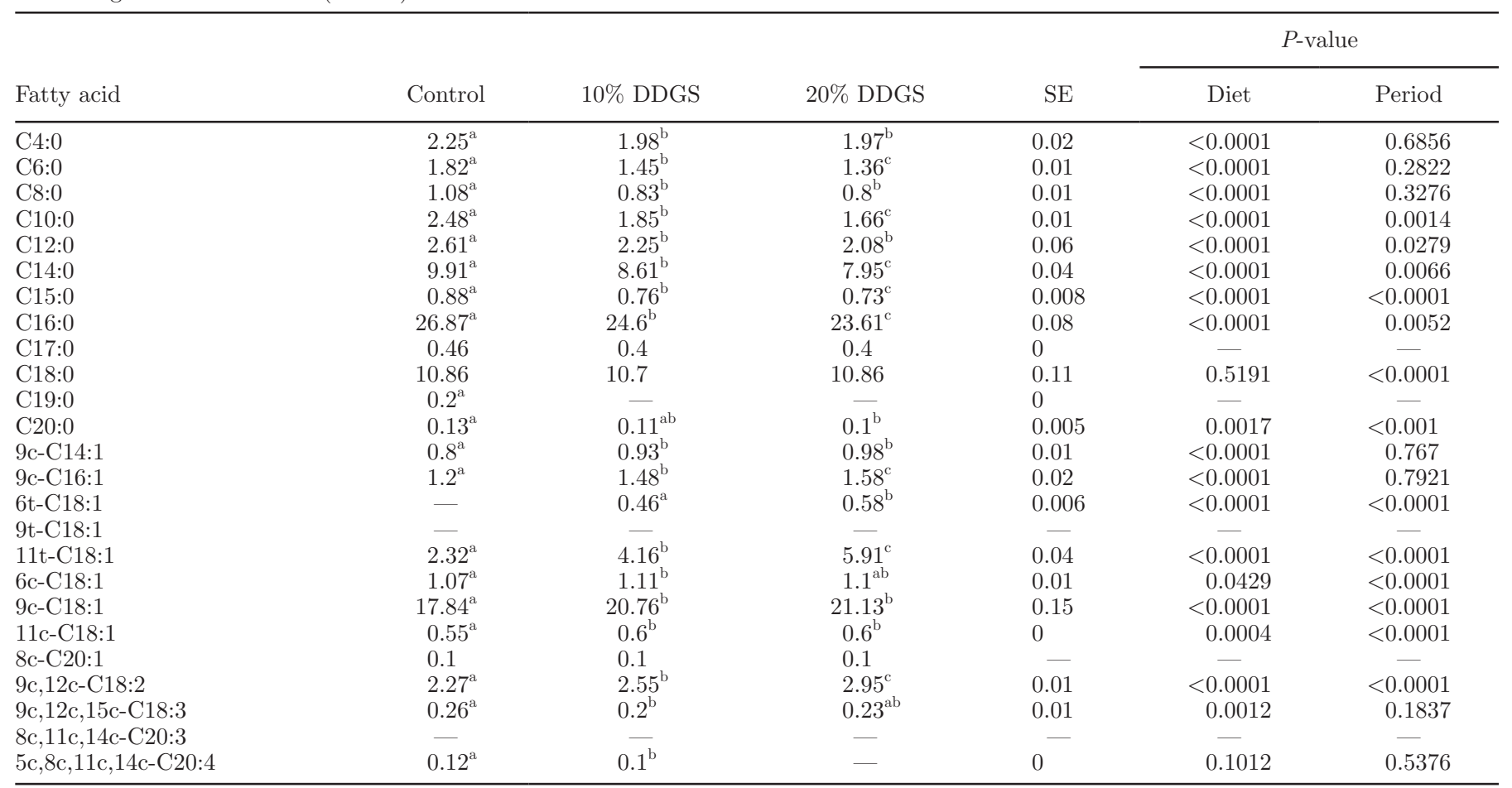

${ }^{\mathrm{a}-\mathrm{C}}$ Values with different superscripts are significantly different $(P<0.05)$.

${ }^{1}$ Nomenclature expressed as number of carbons: number of double bonds. $\mathrm{c}=$ cis; $\mathrm{t}=$ trans.

were found only in trace amounts. The amount of $\mathrm{C} 12$ increased significantly with DDGS feeding, but $10 \%$ DDGS cheese had more C12 than control and 20\% DDGS cheese. All measured long-chain monounsaturated FA increased significantly (9c-C14:1, 9c-C16:1, 6t-C18:1, 11t-C18:1, 9c-C18:1, and 11c-C18:1; c = cis; $\mathbf{t}=$ trans) except 9t-C18:1, 6c-C18:1, and 8c-C20:1. Polyunsaturated fatty acids remained unchanged $(9 \mathrm{c}$, $12 \mathrm{c}, 15 \mathrm{c}-\mathrm{C} 18: 3 ; 8 \mathrm{c}, 11 \mathrm{c}, 14 \mathrm{c}-\mathrm{C} 20: 3$; and $5 \mathrm{c}, 8 \mathrm{c}, 11 \mathrm{c}, 14 \mathrm{c}-$ C20:4) or increased (9c, 12c-C18:2).

Aging time is also sometimes associated with splitting of cheese. White et al. (2003) observed more splitting as the ripening time increased up to $120 \mathrm{~d}$. This is an unlikely explanation for the defects found in the present study because the total cheese ripening time was not more than $90 \mathrm{~d}$.

\section{Spore Testing}

Although modified RCM-lactate is typically used to observe for gas formation by C. tyrobutyricum spores, any gas-producing organism (e.g., propionibacterium) that is capable of utilizing lactate as the sole carbon source and produce gas can grow in this medium. Therefore, RCM-lactate may not be considered a highly selective medium (Wehr and Frank, 2004). However, the heat-shocking $\left(80^{\circ} \mathrm{C}\right.$ for $\left.10 \mathrm{~min}\right)$ step was followed to induce spore germination and eliminate vegetative cells, as the main focus of the research was to identify gas formation by spore-forming bacteria. Additionally, the samples were inoculated in the test tubes containing Durham tubes and allowed to incubate under strict anaerobic conditions, thus inhibiting obligate aerobes. All of these steps were performed to make the medium as selective as possible and to ensure that the conditions would support the growth of Clostridia over other microbes.

No gas formation by spore-forming bacteria was observed when RCM-lactate broth was inoculated with DDGS. The DDGS used in the feeding study was likely devoid of spores because of the high temperatures (up to $426.6^{\circ} \mathrm{C}$ ) associated with the DDGS drying process (Lactrol Technical Information Pamphlet, Pfizer Animal Health, Ridgefield Park, NJ). Pedersen et al. (2004) did not find microorganisms in the wheat wet distillers grains samples collected directly out of a distillation column, but storage in an unclean environment could possibly lead to increases in microbial loads. Under anaerobic conditions, gas formation in RCM-lactate broth was observed in all samples of baby Swiss cheese, 
manure, and the TMR. These results suggest that the TMR or contamination during milking were sources for gas-producing, spore-forming species, and not DDGS.

Herlin and Christiansson (1993) suggested that spores make their way into milk during the milking process through manure-contaminated teats. Butyric acid bacteria and their spores are naturally present in the soil, make their way into feed, and act as a source of contamination in feed and eventually in milk (Vissers et al., 2006). One of the major spore-forming, butyricacid-producing bacteria, $C$. tyrobutyricum is known to be propagated via feed and contaminated milk at the farm level (Houck et al., 2007). Halligan and Fryer (1976) and Dasagupta and Hull (1989) reported large numbers of spores in manure from cows fed silage containing C. tyrobutyricum. Other clostridial species, such as Clostridium beijerinckii, could also end up in cheese, as they are common anaerobic spore-formers found in milk (Klijn et al., 1995). Preventing contamination of raw milk and removing spores from contaminated milk via bactofugation are steps to avoid economic losses because of late-blowing defect, but bactofugation can lead to inferior cheese (Fox et al., 2000; Guggisberg et al., 2015).

Because all cheeses, including cheeses from cows not fed DDGS, exhibited body and texture defects, these findings do not implicate DDGS, but rather gasproducing, spore formers not originating from DDGS, as the likely causative agent for the defects observed. However, we cannot rule out the potential role of elevated milk lactose concentration and changes in FA profile on baby Swiss quality defects.

\section{CONCLUSIONS}

Feeding 20\% DDGS as part of a TMR decreased percentage of fat and increased percentage of lactose and protein in milk. The DDGS source used for this research did not contain thermoduric spores, yet TMR, manure, milk, and cheese contained gas-producing, spore-forming bacteria, demonstrating that the source of the contamination of the milk and cheese by spores was not the DDGS but rather the environment. Because all cheeses, including cheeses from cows not fed DDGS, exhibited body and texture defects, these findings do not implicate DDGS, but rather spores not originating from DDGS, as a contributing agent for the defects observed.

\section{REFERENCES}

Anderson, J. L., D. J. Schingoethe, K. F. Kalscheur, and A. R. Hippen. 2006. Evaluation of dried and wet distillers grains included at two concentrations in the diets of lactating dairy cows. J. Dairy Sci. 89:3133-3142.

AOAC International. 2000. Official Methods of Analysis. 17th ed. AOAC International, Arlington, VA

ATCP (Wisconsin State Legislature. Agriculture, Trade and Consumer Protection). 1996. ATCP 81.91 in Subchapter IX-Baby Swiss Cheese; Standard of Identity and Labeling, Cr. Register No. 481. Accessed Jun. 17, 2015. https://docs.legis.wisconsin.gov/code/ admin_code/atcp/055/81/IX/93.

Cakir, E., and S. Clark. 2009. Swiss Cheese and Related Products. Pages $427-457$ in The Sensory Evaluation of Dairy Products. S. Clark, M. Costello, M. Drake, and F. Bodyfelt, ed. Springer Science \& Business Media, LLC, New York, NY.

Daly, D. F. M., P. L. H. McSweeney, and J. J. Sheehan. 2010. Split defect and secondary fermentation in Swiss-type cheeses - A review. Dairy Sci. Technol. 90:3-26.

Dasagupta, A. P., and R. R. Hull. 1989. Late blowing of Swiss cheese: Incidence of Clostridium tyrobutyricum in manufacturing milk. Aust. J. Dairy Technol. 44:82-86.

Fox, P. F., T. P. Guinee, T. M. Cogan, and P. L. H. McSweeney. 2000. Principal families of cheese. Pages 232-235 and 403-408 in Fundamentals of Cheese Science. P. F. Fox, T. P. Guinee, T. M. Cogan, and P. L. H. McSweeney, ed. Aspen Publishers, Gaithersburg, MD.

Fröhlich-Wyder, M.-T., and H. P. Bachmann. 2007. Swiss cheese. Pages 246-265 in Cheese Problems Solved. P. L. H. McSweeney, ed. Woodhead Publishing Ltd., Cambridge, UK.

Guggisberg, D., P. Schuetz, H. Winkler, R. Amrein, E. Jakob, M.-T Fröhlich-Wyder, S. Irmler, W. Bisig, I. Jerjen, M. Plamondon, J. Hofmann, A. Flisch, and D. Wechsler. 2015. Mechanism and control of the eye formation in cheese. Int. Dairy J. 47:118-127.

Halligan, A. C., and T. F. Fryer. 1976. The development of a method for detecting spores of Clostridium tyrobutyricum in milk. N.Z. J. Dairy Sci. Tech. 11:100-106.

Herlin, A. H., and A. Christiansson. 1993. Cheese-blowing anaerobic spores in bulk milk from loose-housed and tied dairy cows. Milchwissenschaft 48:686-690.

Hettinga, D. H., G. W. Reinbold, and E. R. Vedamuthu. 1974. Split defect of Swiss cheese I. Effect of strain of Propionibacteria and wrapping material. J. Milk Food Technol. 37:322-328.

Houck, K. B., W. L. Wendorff, and R. M. Kaiser. 2007. Distillers grains can add nutrition - and spores. Wisconsin Center for Dairy Research. Dairy Pipeline. 19:4-6.

Hutkins, R. W. 2006. Cheese. Pages 145-205 in Microbiology and Technology of Fermented Foods. R. W. Hutkins, ed. Blackwell Publishing Ltd., Oxford, UK.

Jaros, D., W. Ginzinger, E. Tschager, H. K. Mayer, and H. Rohm. 1997. Effects of water addition on composition and fracture properties of Emmental cheese. Lait 77:467-477.

Johnson, M. E. 2001. Cheese products. Pages 345-384 in Applied Dairy Microbiology. 2nd ed. E. H. Marth, J. L. Steele, ed. Marcel Dekker, New York, NY.

Kleinschmit, D. H., D. J. Schingoethe, K. F. Kalscheur, and A. R. Hippen. 2006. Evaluation of various sources of corn dried distillers grains plus solubles for lactating dairy cattle. J. Dairy Sci. 89:4784-4794.

Klijn, N., F. F. Nieuwenhof, J. D. Hoolwerf, C. B. Van Der Waals, and A. H. Weerkamp. 1995. Identification of Clostridium tyrobutyricum as the causative agent of late blowing in cheese by species-specific PCR amplification. Appl. Environ. Microbiol. 61:2919-2924.

Lawrence, R. C., H. A. Heap, and J. Gilles. 1984. A controlled approach to cheese technology. J. Dairy Sci. 67:1632-1645.

McSweeney, P. L. H., and M. J. Sousa. 2000. Biochemical pathways for the production of flavor compounds in cheeses during ripening: A review. Lait 80:293-324.

Park, H. S., G. W. Reinbold, and E. G. Hammond. 1967. Role of propionibacteria in split defect of Swiss cheese. J. Dairy Sci. 50:820-823.

Pedersen, C., H. Jonsson, J. E. Lindberg, and S. Roos. 2004. Microbiological characterization of wet wheat distillers' grain, with focus on isolation of lactobacilli with potential probiotics. Appl. Environ. Microbiol. 70:1522-1528. 
Steffen, C., P. Eberhard, J. O. Bosset, and M. Ruegg. 1993. Swiss type varieties. Chapter 3 in Cheese: Chemistry, Physics, and Microbiology. Vol. 2. Major Cheese Groups. Aspen Publisher, Gaithersburg. MA.

Tarladgis, B. G., B. M. Watts, M. T. Younathan, and L. Dugan Jr.. 1960. A distillation method for the quantitative determination of malonaldehyde in rancid foods. J. Am. Oil Chem. Soc. 37:44-48.

Tanaka, M., T. Suzuki, S. Kotb, and Y. Kamiya. 2011. Effect of distillers dried grains with solubles (DDGS) feeding to dairy cows on oxidative status under hot condition. Jpn. Agric. Res. Q. 45:457-460.

Testroet, E. D., G. Li, D. C. Beitz, and S. Clark. 2015. Feeding dried distillers' grains with solubles affects composition but not oxidative stability of milk. J. Dairy Sci. 98:2908-2919.

US Grains Council. 2012. A guide to distillers' dried grains with solubles (DDGS). 3rd ed. Accessed Mar. 3, 2015. http://www.ddgs. umn.edu/prod/groups/cfans/@pub/@cfans/@ansci/documents/ asset/cfans_asset_417244.pdf.

Vissers, M. M. M., F. Driehuis, M. C. Te Giffel, P. De Jong, and J. M. G. Lankveld. 2006. Improving farm management by modeling the contamination of farm tank milk with butyric acid bacteria. J. Dairy Sci. 89:850-858.

Wehr, H. M., and J. H. Frank, ed. 2004. Standard Methods for the Examination of Dairy Products. 17th ed. American Public Health Association, Washington, DC.

White, S. R., J. R. Broadbent, C. J. Oberg, and D. J. McMahon. 2003. Effect of Lactobacillus helveticus and Propionibacterium freudenrichii ssp. shermanii combinations on propensity for split defect in Swiss cheese. J. Dairy Sci. 86:719-727. 